\title{
Abandonment vs. Adaptation: Religiosity and the Sustainability of Kenyah Traditional Vocal Performance in Central Borneo ${ }^{1}$
}

Gini Gorlinski, Independent scholar, Chicago, Illinois, United States of America gorloxie@gmail.com

(C) 2017 University of Malaya. All rights reserved. Malaysian Journal of Performing and Visual Arts, Volume 3, 2017

\begin{abstract}
Religiosity, as distinct from religion, can be understood as a particular sense of the contours of the spirit world and of the human relationship with that domain. In communities that have undergone religious conversion, the way in which religiosity is reconciled with the new faith holds great significance for the sustainability of traditional music. This essay examines religiosity as it relates to the choice of the Kenyah of Sarawak, Malaysia, to abandon one type of traditional vocal performance and adapt another following the community's late 20th-century conversion to Christianity. Ultimately, the study underscores the role of social, spiritual, and linguistic contexts and constructs (attitudes) in sustaining traditional music in such post-conversion environments.
\end{abstract}

Keywords: Kenyah, vocal music, religion, religiosity, conversion, sustainability

\section{Preface: Rationale for Retiring a Tradition}

Prior to the mid-1950s, the sound of gongs was an integral and pervasive component of major ritual events among the Kenyah Uma' Jalan of what is now North Kalimantan, Indonesia. By the late 20th century, however, the community had fully adopted Christianity and gongs had all but disappeared from ritual life. Why were the instruments silenced? Why couldn't gong playing simply be adapted or recontextualized to mark Christian ritual activities - notably, Christmas and Easter-as well as the New Year, weddings, funerals, and other ceremonial events?

When confronted with such questions, a respected grandfather in the village of Long Ampung succinctly responded that gongs were adet. While the term adet commonly embraces traditional customs, ways, and habits, as well as personal character, for the Kenyah Uma' Jalan, it often also implies incompatibility with Christian beliefs and values, especially when applied to older indigenous traditions. It was clearly the latter sense in which the grandfather used the term. Playing gongs, he elaborated, constituted a notice, a type of summons directed to Bungan Malan, the supreme deity of the local religion from which most of the village had converted. "It is not fair," he clarified, "to summon a spirit in whom we no longer put our faith. It is also not fair to God, in whom we do have faith, to call that other spirit." In Long Ampung, then, ritual gong playing 
was evidently non-sustainable in the wake of religious conversion. Indeed, the tradition was intentionally retired. 2

\section{Religious Conversion, Religiosity, and Sustainability of Traditional Arts}

The implications of religious conversion or any other change in religious orientation for the sustainability of traditional performing and visual arts are both monumental and wide-ranging across societies. In some settings, traditions associated either with the earlier religion or other indigenous local beliefs are creatively recast, yielding an array of syncretic forms. Malay makyung musical theater and wayang kulit Kelantan shadow-puppetry, for instance, while performed by Muslims, exhibit a blend of spiritual traditions in their narrative repertoire (e.g., Malay folk tales and Hindu epics) and traditional performance contexts (e.g., indigenous healing ceremonies and other local rituals) as well as a mixture of musical aesthetics in their typically Muslim melodic timbres and textures and uniquely Southeast Asian rhythmic frameworks (Matusky \& Tan, 2004). In other settings, however, older traditions are deliberately, if not forcibly, abandoned. Makyung and wayang kulit Kelantan again offer a case in point. While the two traditions have been prohibited since the late 20th century in the Malaysian state of Kelantan on account of their perceived contradiction with the ideals of the conservative Muslim administration, they have been cultivated elsewhere in the country, especially in urban centers and institutions of higher education (Matusky \& Tan, 2004).

Whatever the case, the fate of a given tradition in the wake of religious change depends on many factors, including the attitude of the new religion toward the arts in general, the approach or interpretation of a particular religious denomination, the orientation of a given administration, or even the style of a single religious or political leader. Equally important, however, is the agency of the community itself in determining the course of its artistic traditions in a new spiritual setting. People choose to perpetuate or discard traditions for a reason. Especially in post-conversion contexts, much of that reason, I submit, is rooted in an underlying religiosity - that is, a particular sense of the contours of the spirit world and of the human relationship with that domain. Religion and religiosity, albeit linked, are not the same thing, and it is the way in which people reconcile one with the other that is of tremendous significance for the sustainability of the arts in post-conversion environments.

Religiosity, as I use the term here, implies not necessarily an intense orientation toward any particular religion but rather the interaction and negotiation between multiple religions or spiritual belief systems within a common host. It is a cognitive container in which people store and arrange often conflicting religious beliefs that to some degree are part of their lived experience. This interpretation of religiosity situates my work within a broader corpus of literature concerning communities that consciously or unconsciously juggle a world religion (e.g., Christianity and Islam) with deeply rooted elements of local religion, as exemplified by Joyce Mlenga's 2016 study of "dual religiosity" among the Ngonde of Malawi. Within the Southeast Asian context, local religion typically falls within the realm of adat (or adet), whose role in contemporary social, political, and economic dynamics has been the focus of recent volumes such as The Revival of Tradition in Indonesian Politics: The Deployment of Adat from Colonialism to Indigenism (2007), edited by Jamie S. Davidson and David Henley, as 
well as Adam D. Tyson's Decentralization and Adat Revivalism in Indonesia: The Politics of Becoming (2010). Liana Chua's The Christianity of Culture: Conversion, Ethnic Citizenship, and the Matter of Religion in Malaysian Borneo (2016), with its focus on the adat gawai ritual complex as practiced within a Christian Bidayuh setting in Sarawak, exhibits especially clear parallels with my own research.

In this essay, I will contemplate religiosity, specifically as it relates to the rejection of one vocal performance tradition and the recontextualization of another among the Kenyah of Sarawak, Malaysia, following the community's late 20th-century conversion to Christianity. In addition to the religiosity and adat literature mentioned earlier, then, my study resonates not only with recent publications on music and sustainability, most notably the 2016 anthology edited by Huib Schippers and Catherine Grant, Sustainable Futures for Music Cultures: An Ecological Perspective and Grant's own Endangered Music: How Language Maintenance Can Help (2014), but also with important earlier works and movements, as summarized by Jeff Todd Titon in his contributions to Music and Sustainability (a special issue of The World of Music [2009]). By illuminating some of the local values, beliefs, and attitudes regarding sound, music, and language that together have shaped Kenyah vocal performance, my essay addresses the role of social and spiritual contexts and constructs (see Schippers, 2016) in the sustainability of music. The Kenyah case also demonstrates the interdependent—or symbiotic - relationship between music and language. As will be seen, Kenyah song and verse uses formulaic language that, while quite unlike colloquial speech, is considered to be definitive of truly Kenyah vocal performance tradition. Theoretically, then, loss of one may imply loss of the other (see Grant, 2014).

Material for my musings stems from systematic inquiry (formal interviews), notes on countless casual conversations, as well as analysis of audio and video recordings made during 18 months of research in Kalimantan between 1986 and 1988, 18 months of research in Sarawak between 1992 and 1993, and numerous shorter trips to eastern Malaysia spanning a couple of weeks to several months between 1998 and 2016. Inspired initially by the commentary of that one Kenyah Uma' Jalan grandfather in Indonesia and later by conversations with Kenyah vocalists, church officials, adherents of adet Bungan, and an array of villagers and city dwellers, I will first examine a particular vocal performance tradition that, like the Kenyah Uma' Jalan gong tradition highlighted at the opening of this essay, appears to be unsustainable in contemporary society, on account of its connection to a spirit world with which the Kenyah have discontinued their relationship. Second, and on the flip side, I will show how the church, while often considered culpable in the demise of older performance traditions, has indeed made conscientious efforts to sustain and cultivate them. Ultimately, I will suggest that a grasp not merely of the religion but also of the religiosity of a community is necessary to help guide our efforts to preserve, perpetuate, or propagate traditional musics.

\section{Kenyah Basics-Locations and Livelihoods}

The Kenyah are among the diverse yet related peoples of central Borneo who trace their ancestry to the mountainous area that straddles western North Kalimantan, Indonesia, and southeastern Sarawak, Malaysia. ${ }^{3}$ An ethnically and linguistically 
complex community, the Kenyah comprise more than 40 subgroups ${ }^{4}$ most of which speak a distinct dialect of Kenyah language. Like other central Borneo societies, Kenyah society is stratified into named, hereditary classes, although the distinctions between the classes have diminished significantly since the mid-20th century.

In Kalimantan, Kenyah villages continue to be concentrated in the "homeland"- the Apau Kayan (Kayan Plateau) headwater region of the Kayan River as well as the upper stretches of the Kayan's tributaries, notably the Pujungan, Bahau, and Iwan rivers. In Sarawak, Kenyah settlements are found primarily in the upper Baram and Balui River basins. Downriver migration has been accelerating since the mid-20th century, however, and many Kenyah in both Kalimantan and Sarawak now reside in coastal urban areas or other lower-lying regions where there is greater access to education, hospitals and clinics, employment, and public services. ${ }^{5}$

In the past, most Kenyah villages consisted of one or more longhouses, each partitioned into a number of apartments. All of the apartments were linked in the front by a common veranda that ran the length of the longhouse. As a public area, the veranda provided a venue for community meetings, recreational activities, and ritual events of all sorts, many of which included instrumental and vocal performance. In Indonesia, longhouses have long been discouraged by the government, and they were strategically left behind as part of 20th-century rural resettlement projects. Stand-alone, single-family homes were constructed in their place, with a separate village hall (Indonesian: balai desa) functionally replacing the veranda. By contrast, the Malaysian government has not only offered prizes for model longhouses but has built new longhouses for resettled Kenyah communities. ${ }^{6}$

Village Kenyah are mainly farmers, with most, if not all, of their principal crop-rice -intended for their own consumption. Hunting, fishing, and collecting and cultivating fruits and vegetables provide supplements to the rice staple. In urban or suburban settings, Kenyah are engaged in a broad spectrum of professions - from legislators to lorry drivers - in both the public and private sectors. Some families continue to raise fruits and vegetables in community gardens.

\section{Kenyah Religion and Religiosity—Then and Now}

Phase I: Adet Pu'un. With some regional exceptions, the documented history of the Kenyah of both Malaysian and Indonesian Borneo spans three religious phases: adet pu'un (original adet), adet Bungan (adet of Bungan), and adet Kristen (adet of Christianity). The first phase, adet pu'un 7 , persisted until the mid-1940s or so. This local religion was marked by propitiation of numerous spirits and spirit types. Although none of those spirits could be considered preeminent, some were more important than others, namely Jalong Peselong (Jalong the Creator), a male spirit who was the creator of humankind, and Bungan Malan, his female consort who was the caretaker. A special type of rhythmic, rhyming speech called tebada' was used to address these and other major spirits, who, in turn, conveyed their will through various channels, particularly omen animals (mainly birds), shamans, and dreams. For example, prior to any important undertaking - from embarking on a trip, to conducting a ritual, to opening the planting season, to building a new structure - a hawk (pelaki) was summoned, in rhyme, to ensure an auspicious launch of the activity. When the bird 
appeared, if it circled to the right, it gave a "green light;" on the contrary, its circling to the left triggered a prohibition (palan) and put the activity on hold.

Shamans, or dayung, were an important conduit through which humans could receive advice, warnings, opinions, diagnoses, and other communications from the broader spirit realm. It was possible for a dayung regularly to host any number of spirits (bali dayung, shaman's spirits), one at a time, as long as the community's relationship with those spirits had been ritually sanctioned. Just as people choose their human friends and mentors from a theoretically limitless pool of personalities, so, too, the Kenyah chose a team of spirit helpers through the shaman.

Phase II: The Adet Bungan Transition. Protestant missionaries based in the United States began to work in the Pujungan watershed in Kalimantan in the early 1930s. Within just a few years an entire Kenyah village had embraced Christianity (Rudes, 1965), and the number of converts subsequently rose rapidly. This powerful wave of Christian conversion spawned a strong, albeit relatively short-lived, rival religion known as adet Bungan. As the story goes, about 1937, Juk Apui, a Kenyah Uma' Jalan commoner from the upper Kayan River, had a prophetic dream. In that dream, Bungan Malan of the adet pu'un pantheon appeared to Juk, bearing the message that it was no longer necessary for the Kenyah to heed the omen animals or propitiate numerous spirits; rather, the people needed only to put their faith in her, and she would take care of them. Bungan also indicated that a single chicken egg would suffice as offering in most ritual circumstances - a monumental reduction from the numerous pigs and chickens required under adet pu'un (see Figure 1). Juk followed Bungan's advice, and to the dismay of the surrounding community, enjoyed an abundant harvest the following season. Consequently, adet Bungan began to gain adherents.

As a simplification of adet pu'un that rendered life more predictable, less expensive, and altogether more manageable, adet Bungan spread quickly in the upper Kayan River region. It soon crossed the watershed into Sarawak, and by the mid-1950s had been adopted not only by most Kenyah but also by a number of neighboring peoples (especially Kayan) in the upper Baram and Balui basins. While adet Bungan retained the spirits and major rituals of adet pu'un, it simultaneously adopted some characteristics of Christianity, including the use of missionaries, and most notably, the elevation of Bungan Malan to the status of supreme being, where none had existed before. This is likely what prompted an elderly Sarawak Kenyah villager to describe adet Bungan as transitional, that is, setenga sebayang (halfway praying, or halfway to Christianity). ${ }^{8}$ 


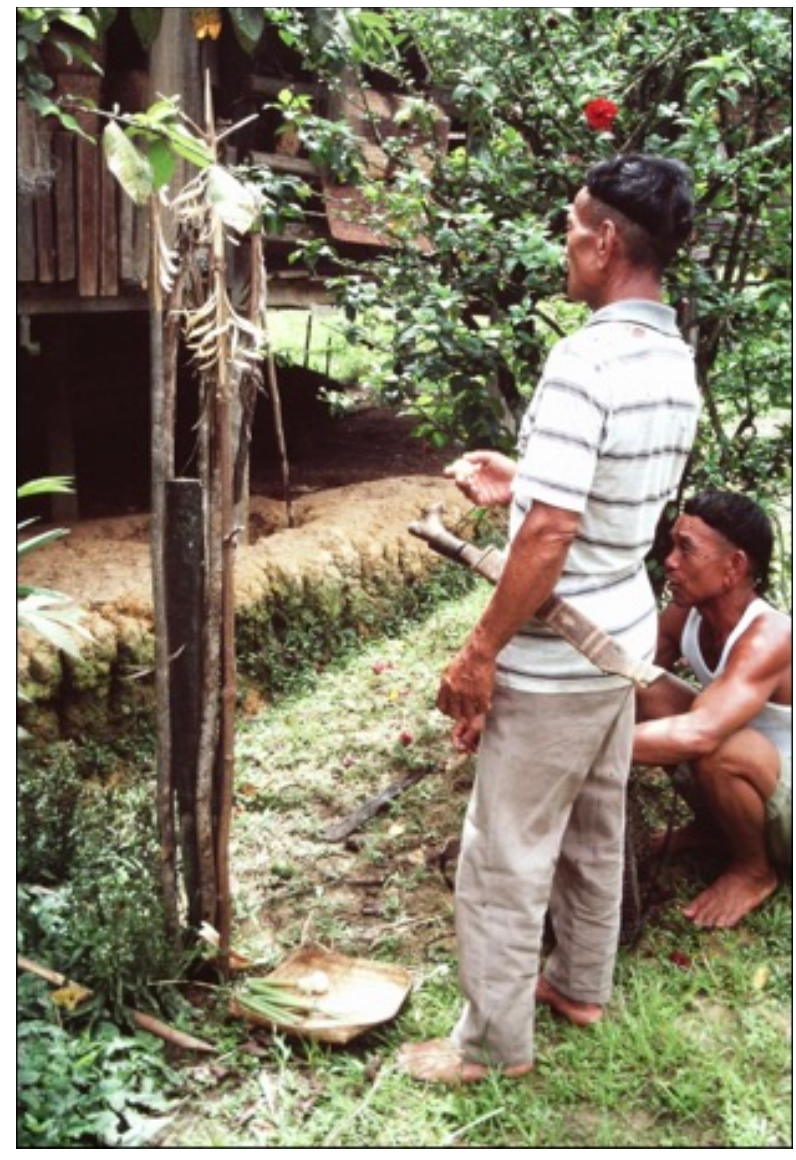

Figure 1. Adet Bungan practitioner Pigang Langgang reciting tebada' over a ritual chicken egg as part of harvest rituals. Long Moh, Ulu Baram, Sarawak. March 10, 1993.

Phase III: Adet Kristen-Christianity. By the time adet Bungan began to flourish in Sarawak in the 1950s, it was in its twilight in Kalimantan. By the mid-1940s, many of the Pujungan villages had already converted to Christianity and major congregations had also been established in the Apau Kayan (Conley, 1976). Other missionaries arrived, and large-scale conversions, primarily to one of several Protestant denominations, took place in Indonesian Borneo in the mid-1960s. ${ }^{9}$ Catholicism, while present as a significant minority among the Kalimantan Kenyah, had greater influence among the Sarawak Kenyah, where it established a particularly strong following in the upper Baram basin. While adet Bungan remained influential in Sarawak longer than it did in Kalimantan, by the end of the 20th century, there, too, it had virtually disappeared, with the functions of Bungan Malan, the shamans and their associated spirits, and any remaining omen animals having been assumed by the Holy Trinity and Christian spiritual leaders.

Major adet pu'un rituals were retained in adet Bungan, and some, too, were retained in the Christian environment-but not uniformly throughout the Kenyah community. A notable example here is the village-wide child-naming ritual, ngalang anak (or pusau anak), which continues to be performed every decade or so by various Kenyah villages in Sarawak, especially in the upper Baram basin. Of course, the ritual has been adjusted to suit the Christian context, and the distinction was especially conspicuous at 
the ngalang anak as performed in the village of Long Moh in the upper Baram basin, in 1992. At the time, Long Moh was predominantly Catholic but also had a practicing, albeit small, adet Bungan community. Followers of the two religions held their rituals separately. Aside from the Christian version being conducted by a priest and the adet Bungan version being conducted by an adet Bungan ritual specialist, among the most salient of the distinctions between the two events was a sonic one. The officiation of the Christian ritual was relatively calm, as the priest solemnly proceeded down a line of children, who were seated with their families on the longhouse veranda, and blessed each child with the Christian name that was handed to him on a slip paper (see Figure 2). By contrast, the officiation of adet Bungan ritual was deafening, as the raucous interlocking rhythms of heavy gongs obscured the ritual specialist's speech-including tebada ' - as he waved a chicken in the air, decapitated it, and smeared a mixture of its blood and ashes on the forehead of each child participating in the ceremony (see Figures $3 a$ and $3 b)$.

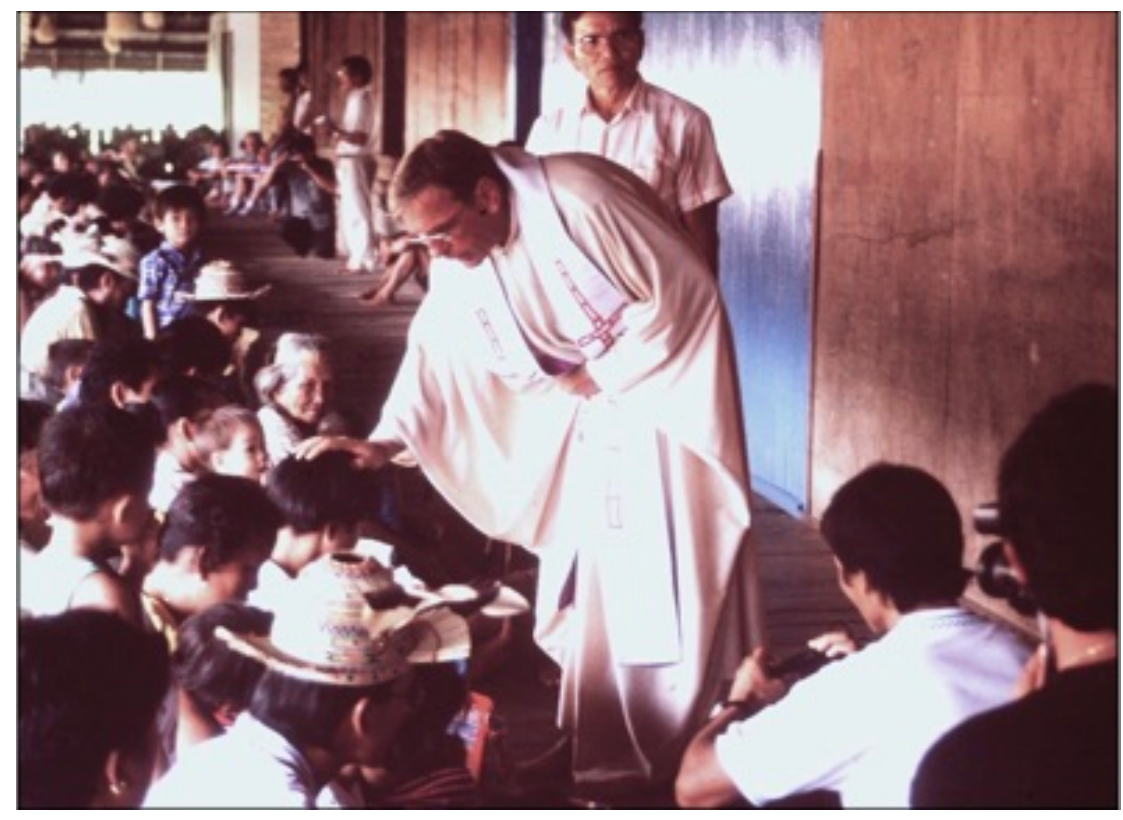

Figure 2. Father Albert Jacobse blessing children at the ngalang child-naming ritual. Long Moh, Ulu Baram, Sarawak, Malaysia. June 6, 1992. 


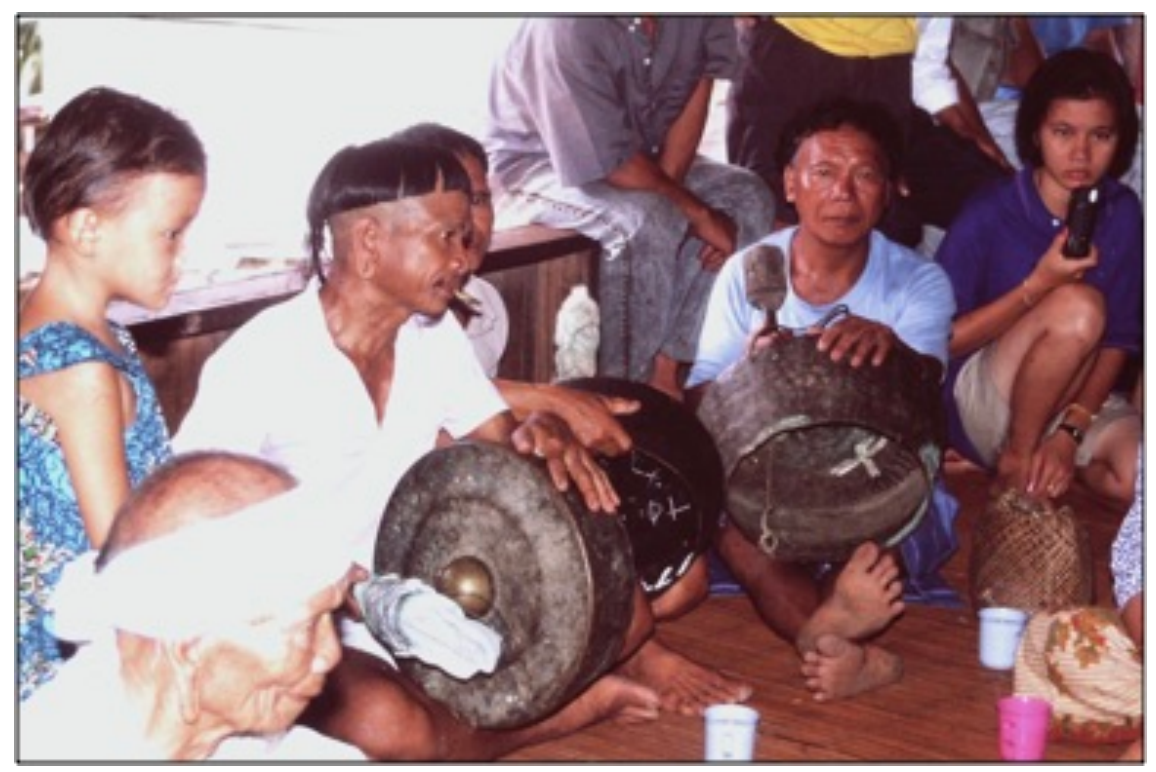

Figure 3a. Members of adet Bungan community playing gongs during officiation of ngalang child-naming ritual. The ritual specialist is wearing the white head scarf (lower left). Long Moh, Ulu Baram, Sarawak, Malaysia. June 5, 1992.

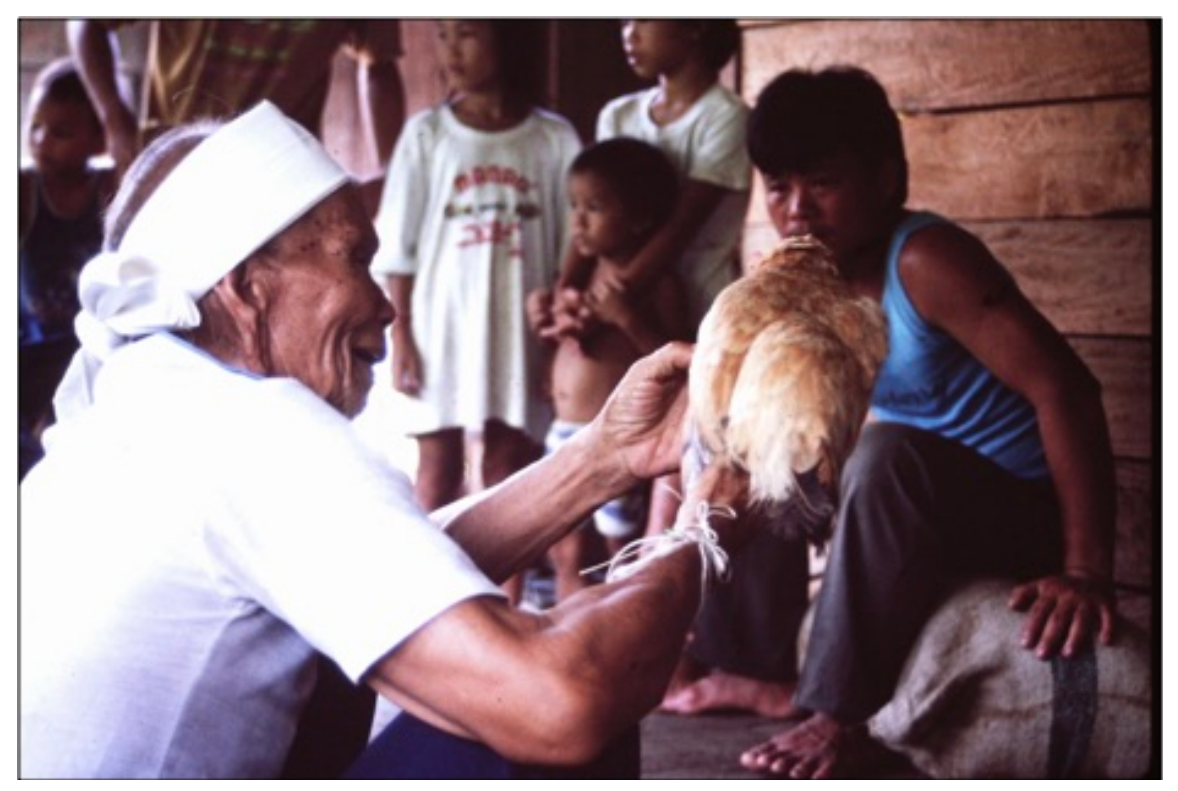

Figure 3b. Adet Bungan ritual specialist Dudung Ding reciting tebada' over a chicken as part of the ngalang child-naming ritual. Long Moh, Ulu Baram, Sarawak, Malaysia. June 5, 1992. 


\section{Kenyah Religiosity: An Orientation That Withstood Conversion}

Although Kenyah religion underwent a radical transformation during the 20th century, the underlying religiosity of the Kenyah did not-at least initially. From a Kenyah perspective, the spirits of adet pu'un and adet Bungan were just like people. Some spirits were liked; others were not. Some were trustworthy; others lied. Some lived in one spirit village; others lived in another. Some spoke one language; others spoke another. The point is that each spirit was a unique entity with an individual personality. The Christian God and Jesus, too, represented distinct figures. Considering the humanlike qualities of traditional Kenyah spirits, it only makes sense that relationships with them were treated in much the same way as relationships with humans. Jalong Peselong, Bungan Malan, the shamans' spirits, as well as other spirits of adet pu'un and adet Bungan remained available after Kenyah conversion. The Kenyah pattern, however, was to cease interacting with them, because in a sense, the relationships had broken up.

An elderly woman from Long Mekaba in the upper Baram basin recalled ending the relationship with the shamans' spirits. "We called them, we thanked them, and we told them that we wouldn't be needing them anymore." The break-up was essentially on friendly terms. Nevertheless, with the severance of that relationship, a principal conduit of communication with the spirit world of adet pu'un and adet Bungan was ruptured. Another woman mused, "The spirits weren't bad. They were just the wrong ones." The "right" spirit was the Christian God (or the Holy Trinity), who offered a much more straightforward and convenient religious alternative for the Kenyah. 10 Thus, a new spirit relationship emerged, while another was deactivated-and the status of those relationships needed to be respected.

\section{Tales of Abandonment and Adaptation}

In the "Science and the Arts" section of almost every issue of the Sarawak Annual Report between the early 1960s and the early 1980s, the waning of traditional arts was attributed to "new values" brought by "western civilization", specifically, by missions and government schools.11 I would suggest, however, that to a significant degree, it is precisely the "old values" as manifested in a long-standing religiosity that put a halt to many performance traditions. Whether performed in recreational or ritual circumstances, most Kenyah traditional music was connected in some way with one or more of those spirit realms with which relations had been discontinued when the community accepted Christianity. Depending on the nature of those connections, the Kenyah opted to abandon some traditions, despite valiant efforts by the church to sustain them, and to adapt others, ultimately generating new, distinctively Kenyah performance traditions that span recreational and ritual contexts.

Tebada': Versification Left Behind. One such tradition that the church struggled to salvage was tebada', that special rhyming language used to interact with the major spirits of adet pu'un and adet Bungan. Tebada' was a kind of versification, performed solo by a ritual specialist. It was non-melodic, rhythmically declaimed, formulaic, and marked by a high degree of internal alliteration and assonance. Like similar ritual languages of the Indonesian archipelago ${ }^{12}$, it was dense with metaphor and replete with strings of synonyms and words borrowed from other languages. The example below 
illustrates a short segment of tebada' that humbly expresses the inability of humans to address Bungan Malan appropriately. Borrowed words-from a different Kenyah dialect in the fifth line and from Malay in the sixth — appear in boldface.

In an effort to facilitate prayer and likely also to indigenize Catholicism within the Kenyah community, Reverend A.D. Galvin in 1972 issued Sebayang Singget Tau (Prayers for Every Day), a book of Catholic prayers and rituals recast primarily in Kenyah tebada'. My first exposure to the collection was when my adoptive Kenyah father pulled it from the roof beams of our longhouse apartment in Long Moh in 1993. I was certainly surprised. Never had I heard tebada' used to any significant extent in Sunday masses. "Do you use this?" I asked my father. "No, we don't use it," he replied, with no further explanation.

Table 1

Tebada' to Address Bungan Malan (an excerpt)

Performed in 1993 by Dudung Ding, Long Moh, Upper Baram, Sarawak

\begin{tabular}{|l|l|}
\hline \begin{tabular}{|l|} 
Ini sepini la'a, bali tiga bali \\
liwa ini,
\end{tabular} & $\begin{array}{l}\text { Then this again, good spirit, } \\
\text { this spirit of the liwa [ritual } \\
\text { stick, the end of which was } \\
\text { shaved into curls and } \\
\text { dipped in chicken blood] }\end{array}$ \\
\hline Iko' ngimet iko' na'at, & You think, you look, \\
\hline Ban amé' kelunan na, & For we humans, \\
\hline \begin{tabular}{|l|l|} 
Bé' mé' tisen tira' tebada' \\
ngan ju',
\end{tabular} & $\begin{array}{l}\text { We don't know how to } \\
\text { speak, to ritually talk with } \\
\text { you, }\end{array}$ \\
\hline Ta'at tepai ta'at salai & $\begin{array}{l}\text { The sight of our calling } \\
\text { [you], the sight of our poor } \\
\text { condition, }\end{array}$ \\
\hline $\begin{array}{l}\text { Ban ikut menurut dahu } \\
\text { pa' dahu tira', }\end{array}$ & $\begin{array}{l}\text { For we [just] follow, } \\
\text { according to the sound of } \\
\text { the mouth, the sound of } \\
\text { speech, }\end{array}$ \\
\hline $\begin{array}{l}\text { Uko' ko' tu'a namé', kele, } \\
\text { Bungan. }\end{array}$ & $\begin{array}{l}\text { Because you are foremost, } \\
\text { of course, Bungan. }\end{array}$ \\
\hline
\end{tabular}


Several years later I discussed the matter with Vincent Bilung, a Kenyah catechist who had worked with both Galvin and Francis Baartmans, a Dutch priest who also had served the Baram Catholic community. The catechist explained that it was the "white people" who wanted to use tebada'. It was they who initially wanted to call God by the name of Jalong Peselong Luan (Jalong "the Creator of the human body"), after the prominent male spirit of the adet pu'un pantheon. It was the foreign priests who wanted to refer to the Holy Ghost as "Bali Utung" (Protective Spirit), after a spirit possessed by every individual - and unique to that individual-during the adet pu'un and adet Bungan eras. Indeed, references to God as "Peselong Luan" and the Holy Ghost as "Bali Utung" can be found throughout Galvin's prayer books. It was the Kenyah congregation, the catechist stressed, that generally rejected such reassignment of those appellations as well as the use of tebada' in the Catholic mass. Just as the grandfather in Long Ampung had told me that the striking of gongs belonged to Bungan Malan, the language of tebada', it seemed, also belonged to the principal spirits of adet pu'un and adet Bungan, and it was non-transferrable.

Catechist Vincent went on to reveal that he was working on a new Kenyah translation of the New Testament, into which he hoped to incorporate tebada'. He admitted, however, that he had to proceed with caution. While some members of the congregation were beginning to show interest in reviving tebada', others perceived the language still as intimately tied to a non-Christian spirit world. Posing an additional obstacle to the resurrection of tebada' was the fact that for younger Kenyah - basically, anyone born since the mid-1960s - the stylized language was especially difficult to understand; they had simply not been exposed to it in the way their parents had. One young priest from the Balui basin, for instance, told me that tebada' made no sense to him whatsoever. Consequently, he would not consider using it in his service. Despite some admirable efforts on the part of the clergy to sustain the uniquely powerful language and performance of tebada', then, it was ultimately the Kenyah congregation itself that let the tradition go.

Belian Dadu': A New Adaptation. Belian dadu', or long-dance songs, have become the best known of all Kenyah song repertoires since their advent in the mid-20th century. Like tebada', long-dance songs are linked to the spirit world of adet pu'un and adet Bungan, specifically through the nature of their language. In terms of the style, content, and context of their performance, however, belian dadu' are notably distinct from tebada'. Most significantly, reinterpreted long-dance songs have been incorporated successfully into Christian services, despite any connections to a nonChristian spirit realm. A look at the nature and history of belian dadu' can help us understand how an enduring Kenyah religiosity allowed this repertoire to be sustainable in a Christian environment. 


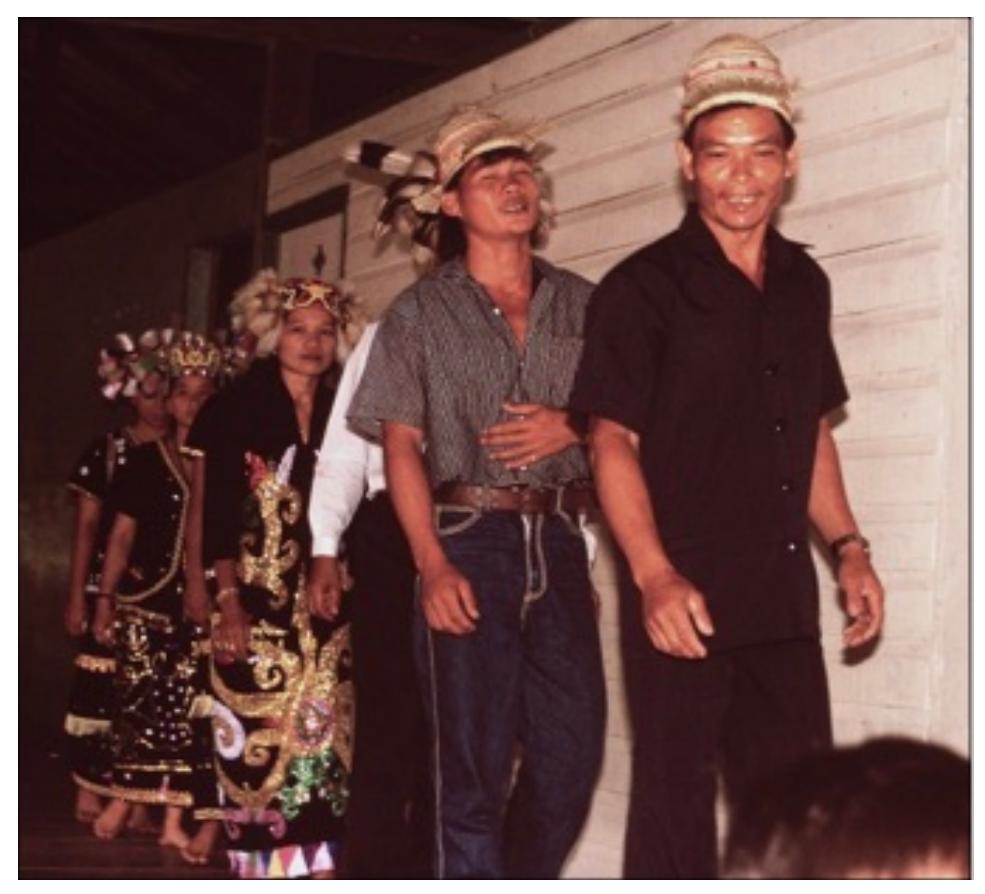

Figure 4. Men and women singing recreational belian dadu' (long-dance songs) while processing up and down the longhouse in celebration the ngalang child-naming ritual. Long Moh, Ulu Baram, Sarawak, Malaysia. June 6, 1992.

Long-dance songs are typically heard at any large-scale Kenyah festivity that includes participants from multiple villages or locales. The songs are normally performed by a single line of dancers who process in a circle up and down the longhouse veranda (Figure 4), or in absence of a veranda, any large, open space (usually indoors). In village settings, performances normally take place at the start of a larger dance event as a way both to signal that the main activities are about to commence and to allow time for a crowd to gather. As more and more people arrive at the venue, the line of dancers grows longer and longer. In urban settings, belian dadu' are often scheduled into a broader program of events as a way to evoke the atmosphere and camaraderie of the rural homeland. 13

Stylistically, belian dadu' occupy a unique position in the corpus of Kenyah song. Like other Kenyah song repertoires, long-dance songs consist of an alternating solo and choral part. However, both the soloist and the chorus perform melodically in belian $d a d u$, whereas in most other types of Kenyah song, the melody of the soloist is supported by an intermittent monotone chorus that functions essentially as a drone. Also atypical is the structure of belian dadu', which is basically strophic - although there is no set order in which the strophes must be performed. Most long-dance songs use an anhemitonic-pentatonic scale of the M2-M2-m3-M2-m3 (e.g., c-d-e-g-a-c) type, while hemitones and even smaller intervals are frequently used in other Kenyah song genres. Finally, the chorus in belian dadu' will often break into parts, usually at the interval of a third or fourth, depending on the contour of the melody (see Figure 6).

The earliest accounts of belian dadu' (or songs that fit the description) date from the years just following World War II. One Long Moh grandfather recalled witnessing long-dance songs about 1946-47, when he travelled with a group to a Kenyah 
community living on the Bahau tributary of the Kayan River in Kalimantan, Indonesia. Significantly, that region already had a strong Christian following. According to that same Kenyah grandfather, songs of the type that he heard in Kalimantan arrived in Sarawak's upper Baram basin by way of the Apau Kayan later in the 1940s.

In light of the era and area of the long-dance songs' emergence, it is not unreasonable to speculate that the peculiar character of the repertoire-strophic, melodic, choral singing in parts - was inspired by Christian congregational hymn singing. William Conley (1976), in his account of the Protestant conversion of the Kalimantan Kenyah, not only commented on the augmented role of hymn singing in the Kenyah services but also indicated that:

Most of the hymns are a legacy from the mission and consist of western tunes with Indonesian words translated quite literally from the English. The Kenyah happily are putting their language to some of these tunes and also Kenyah folk tunes have been given Christian words. (pp. 333-334)

Conley did not give any text or music transcriptions to illustrate this cross-fertilization between traditional Kenyah songs and Christian hymns. Consequently, it is difficult to determine the nature of the Kenyah language used to set the church tunes as well as what "Christian words" were added to which "folk" melodies. What is evident, however, is that in Kalimantan, Kenyah-propelled musical exchange was already well underway by the time Galvin compiled his prayer book in Sarawak. Belian dadu', I suggest, were an early, recreational product of that exchange.

By the late 20th century, all but the oldest Kenyah in both Kalimantan and Sarawak understood belian dadu' to have been passed down by dia 'lata' cena' 'a' (the great ones of the past) from time immemorial. No connection to hymn singing was perceived whatsoever. For most Kenyah, belian dadu' had come to represent an unmistakably Kenyah tradition. That the songs were stylistically unlike other Kenyah repertoire was inconsequential. The feature that served to so indigenize the repertoire, I posit, is the special register of Kenyah language in which the repertoire is cast-isiu belian (language of song), also known as isiu ipet (language of verse), or most significantly, isiu bali (language of spirits). 14

Like the language of tebada', Kenyah song language stands apart from ordinary speech in that it is formulaic, highly metaphoric, inclusive of non-linguistically meaningful words as well as words from other languages and dialects, and marked by strings of synonyms, internal assonance, and alliteration. The phrases of typical song language, in addition, lead to the end rhyme, "-an." Unlike the language of tebada', which humans used to call and address important spirits, the language of song or verse was used by spirits to communicate with each other and, through the shamans, to address humankind. Indeed, the Kenyah language of song was and is the language of spirits, which, from a common local perspective, explains why the language is not fully comprehensible to human audiences. Owing to its nebulous, indirect quality, the language of spirits was perceived as powerful, respectful, and honorable. Consequently, the "great ones of the past" purportedly borrowed the language to use in the performance of respectable recreational songs, that is, songs that are ultimately 
used to honor others. Songs that are cast in this special isiu belian song-cum-spirit language are typically perceived as traditional Kenyah songs. ${ }^{15}$ Vocal repertoires such as translated church hymns or pop songs that use ordinary Kenyah as opposed to the distinctive song language occupy a different conceptual category; they are not normally acknowledged as true Kenyah songs.

The Kenyah language of song, then, constitutes a powerful marker of Kenyah identity, and because it could be used recreationally - that is, without notifying or summoning spirits (unlike tebada') - the Catholic church in Sarawak recognized its value as a tool to help indigenize the local services. As a result, the church was safely able to retext some belian dadu' with Christian words - skillfully manipulating the formulae of song language - and distribute the songs initially in a small section at the end of Galvin's Sebayang Singget Tau (1972). A second version of the volume was issued in 1975, and although much shorter than the original, contained a substantially expanded song section. Retexted belian dadu' also appeared in the anonymously authored booklet, Puji Tuhan (n.d.; Praise the Lord) that, although undated, seems to be a more recent compilation.

In the left column of the table below are the lyrics of "Song No. 19" (colloquially known as "Ngening Denga," ["Hear the News"]), a retexted belian dadu' from Galvin's 1975 volume. The original parsing and punctuation have been adjusted here to show the rhyme structure more clearly. A loose translation appears in the column on the right. In the Kenyah version, the characteristic assonance and alliteration are especially pronounced between the second word and the last one or two words of the first phrase of each verse. The verses close with the distinctive end rhyme, -an. The translation on the right reveals the evocative metaphors and strings of synonyms (or words that are very close in meaning) that also are hallmarks of Kenyah isiu belian.

The first verse of "Song No. 19," as performed by a small group of Kenyah at Uma' Badeng at Sungai Asap in 1999, is notated in Figure 5. The complete performance included all four verses, sung in the order in which they appear in Sebayang Singget Tau. In the fashion of belian dadu', the performance consisted of a soloist, who initiated the verse, and a chorus that picked up the melody mid-phrase and sang the verse to completion. On this particular occasion, the performers were hesitant to break into intervalic part singing, although a start is evident in the eighth and ninth measures after the double bar. The melody uses an anhemitonic pentatonic scale, which, as noted, is common in the long-dance song repertoire, and from a rhythmic perspective, the time signature here can be taken literally, as the group performed in a steady tempo and meter. 
Table 2

"Song No. 19” from Sebayang Singget Tau (1975:13)

\begin{tabular}{|c|c|}
\hline $\begin{array}{l}\text { Ame' anak iko'ini lundung } \\
\text { (sic) tenak, } \\
\text { lendung tenak nyibung } \\
\text { bu'an. }\end{array}$ & $\begin{array}{l}\text { We, your children, branching } \\
\text { growth, branching growth, fruit of } \\
\text { the nyibung palm. }\end{array}$ \\
\hline $\begin{array}{l}\text { Ngening denga, ngening } \\
\text { denga iko'amai atek tiga, } \\
\text { atek tiga pesalawan. }\end{array}$ & $\begin{array}{l}\text { Hear the news, hear the news, } \\
\text { father, truly good, } \\
\text { truly good, beautiful. }\end{array}$ \\
\hline $\begin{array}{l}\text { Ame’pejung iko'amai kipet } \\
\text { batung, } \\
\text { kipet batung usa inan. }\end{array}$ & $\begin{array}{l}\text { We hold you up high, every } \\
\text { person, } \\
\text { every person, body, tree trunk. }\end{array}$ \\
\hline Ngening denga. . . & Hear the news. . . \\
\hline $\begin{array}{l}\text { Kuda'masé'iko'amai lesau } \\
\text { lan sa'e, } \\
\text { lesau sa'e dalem inan. }\end{array}$ & $\begin{array}{l}\text { May you pity, father, feel truly sorry } \\
\text { thoughts, } \\
\text { feel sorry thoughts inside the tree } \\
\text { trunk. }\end{array}$ \\
\hline Ngening denga. . . & Hear the news. . . \\
\hline $\begin{array}{l}\text { Ayen lipau iko'amai turan } \\
\text { lan salau, } \\
\text { turan salau sa'e uyan. }\end{array}$ & $\begin{array}{l}\text { Don't be distant, father, truly } \\
\text { enjoying, making good thoughts. }\end{array}$ \\
\hline Ngening denga. . & Hear the news. \\
\hline
\end{tabular}



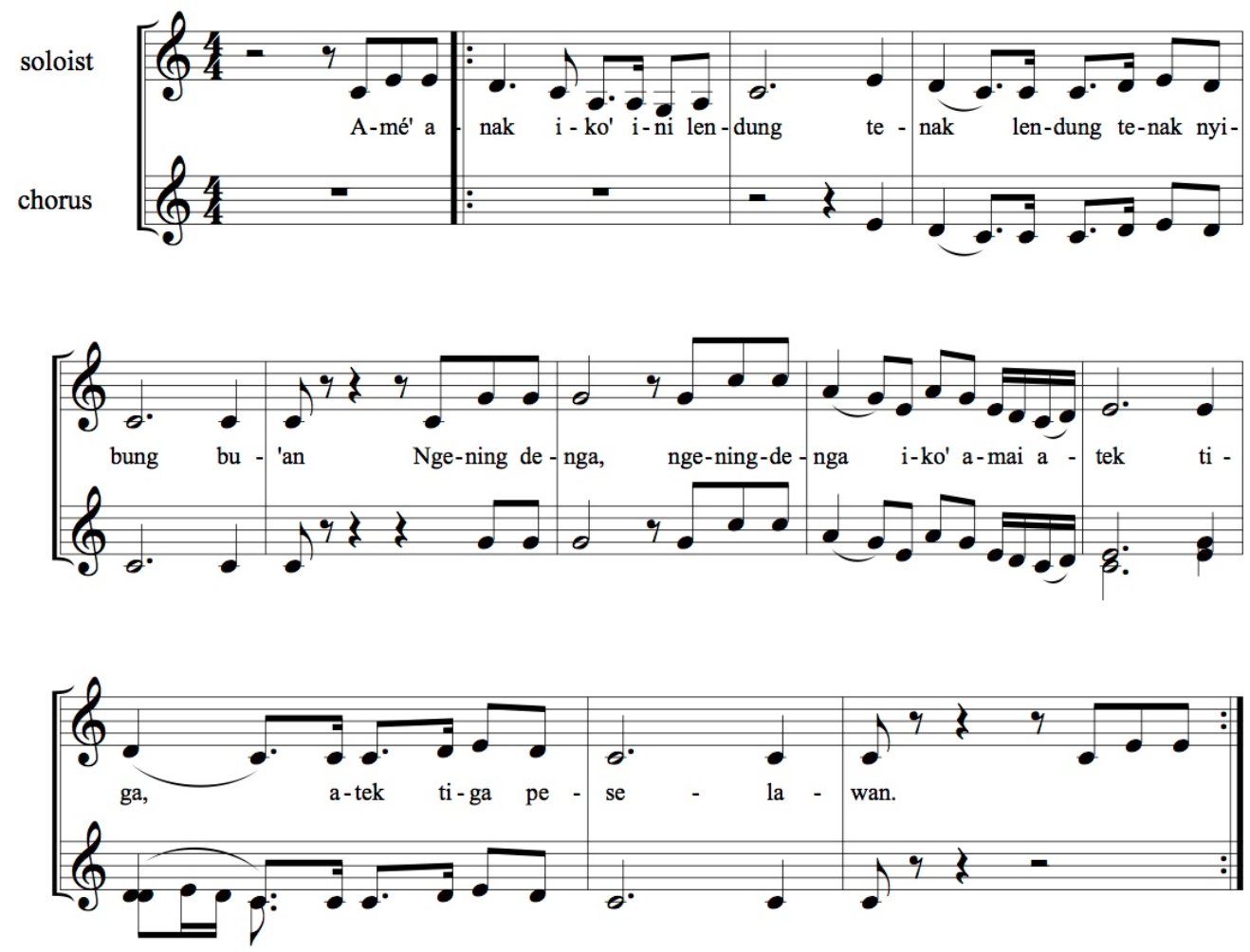

Figure 5. First verse of "Song No. 19" (also known as Ngening Denga), as performed at Uma’ Badeng, Sungai Asap, Belaga, Sarawak, Malaysia. August 6, 1999.

Now, let us compare "Song No. 19" with its recreational predecessor, the well-known long-dance song, "Léléng" (circling). While both the printed version and the actual performance of "Song No. 19" by the Kenyah at Sungai Asap would suggest a fixed and finite text, every traditional rendition of "Léléng," by contrast, is unique. As with other long-dance songs, some performances of "Léléng" are short while others are long, and the verses vary in number and content depending on the whims of the performers and their command of the formulaic language of song. Shown in the following table is a text excerpt from a 1999 performance of "Léléng" in Long Moh. Again, the typical assonance and alliteration-here mostly between the second or third word and the last word of the first phrase of each verse - as well as the recurring -an end rhyme are readily apparent with a quick scan of the text on the left. Similarly, the translation on the right is clearly packed with colorful, semi-transparent metaphors and series of synonyms. To clarify some of the imagery, the term léléng (circling), which dominates the refrain, refers to the circling line of the long-dance participants. "Along," which is also used in the refrain, is a proper noun-a person's name. "Uyau Along" is the male version of that name; "Utan Along" is the female version. In longdance and other recreational songs, "Along" is used to sing about or to a particular individual without saying that person's actual name. In the second verse, the soloist expresses humility by acknowledging the poor quality of her voice, likening its hoarseness to the sound of a palm stem, which is an oblique reference to a palm-wood jew's harp. 
Table 3

Belian Dadu' "Léléng” (an excerpt)

As performed in Long Moh, Upper Baram, Sarawak, Malaysia, 22 June 1999

\begin{tabular}{|c|c|}
\hline $\begin{array}{l}\text { ‘em ini anak na tepat pemung } \\
\text { jahi, } \\
\text { pemung jahi suwi lawan. }\end{array}$ & $\begin{array}{l}\text { Tonight, children, we all socialize } \\
\text { together, } \\
\text { socialize together, } \\
\text { beautiful birds. }\end{array}$ \\
\hline $\begin{array}{l}\text { Léléng, léléng, léleng, } \\
\text { léléng, léléng, Uyau Along, } \\
\text { léléng, oi lan. }\end{array}$ & $\begin{array}{l}\text { Circling, circling, circling, } \\
\text { circling, circling, Uyau } \\
\text { Along, oh it's true. }\end{array}$ \\
\hline $\begin{array}{l}\text { Bung baré naké' anak tuyau } \\
\text { lidé, } \\
\text { tuyau lidé talan jaran }\end{array}$ & $\begin{array}{l}\text { I am hoarse, child, sound of } \\
\text { palm stem, } \\
\text { sound of the palm-wood stem } \\
\text { jaran [no recognized linguistic } \\
\text { meaning] }\end{array}$ \\
\hline Léléng, léléng.. . & Circling, circling. . . \\
\hline $\begin{array}{l}\text { Na pesempa' tepat anak } \\
\text { dahu tira', } \\
\text { dahu tira' ti patapan. }\end{array}$ & $\begin{array}{l}\text { Affectionate, sound of our talking, } \\
\text { children, } \\
\text { sound of our talking, making } \\
\text { speech. }\end{array}$ \\
\hline Léléng, léléng. . . & Circling, circling. . . \\
\hline $\begin{array}{l}\text { Mahu' na nai niko' metik lan } \\
\text { sungai, } \\
\text { metik sungai limun kanan. }\end{array}$ & $\begin{array}{l}\text { After all you truly travel up } \\
\text { the river, } \\
\text { travel up the river limun } \\
\text { [no recognized linguistic } \\
\text { meaning] of use. }\end{array}$ \\
\hline Léléng, léléng. . . & Circling, circling. . . \\
\hline
\end{tabular}

Notated in Figure 6 is the melody of "Léléng" as composited from two separate performances that together reflect the distinctive qualities of the belian dadu' song genre. 

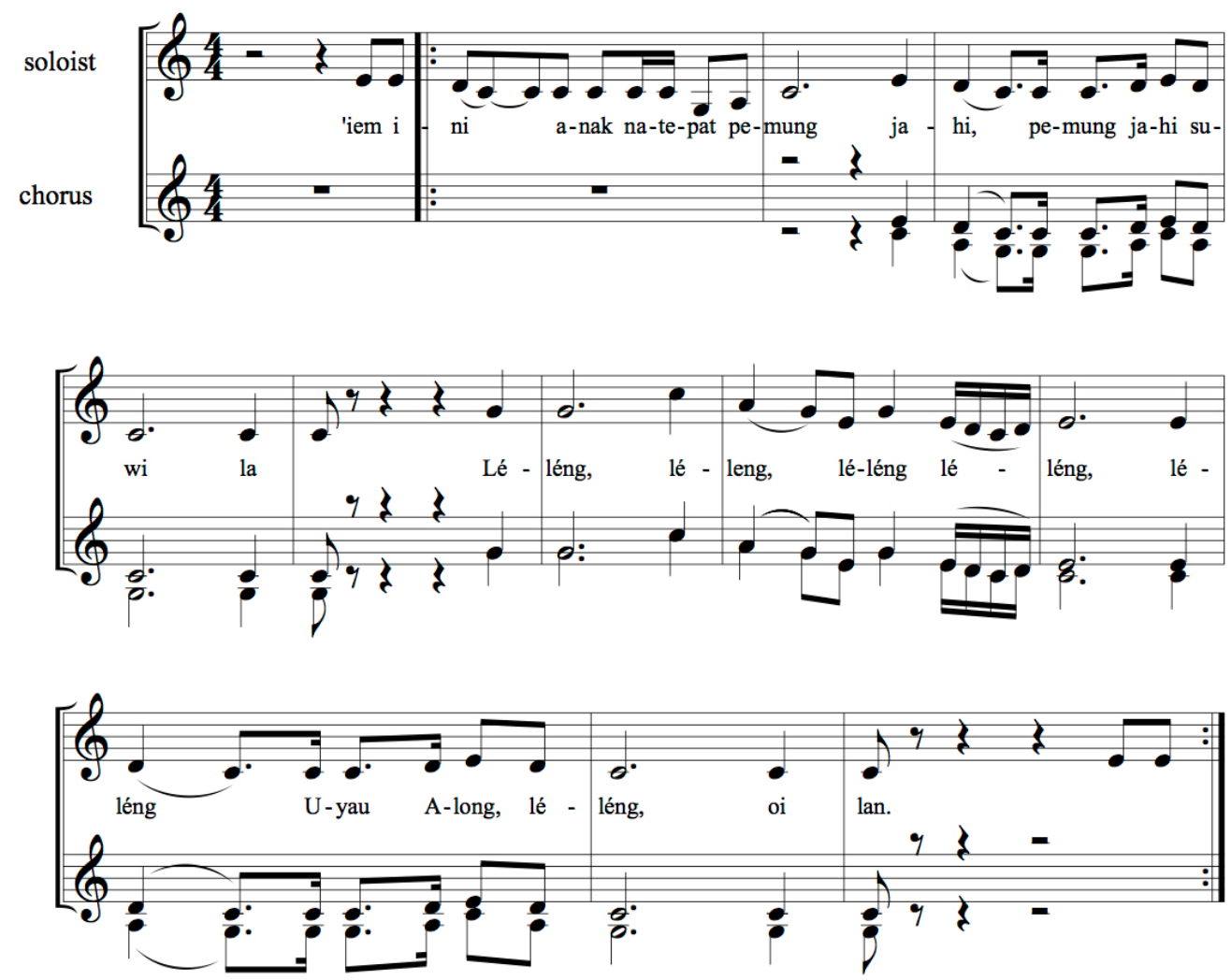

Figure 6. A verse of "Léléng" composited from two performances in Long Moh, Upper Baram, Sarawak, Malaysia. The first performance, on February 3, 1993, had stronger part singing; the second, on June 22, 1999 had clearer text.

Note that the main melody of the song is virtually identical to that of "Song No. 19." Unlike its Christian counterpart, however, the tempo and meter of the "Léléng" performances were much more flexible, particularly at the sustained pitches and at the end of each phase. Although the performances from which this transcription was made occurred out of context, with the singers seated in a closed room, even when sung by long-dance participants, there is often a notable ebb and flow to the singing, as the dancers wait for a soloist to begin a verse and as the soloists slow the tempo a bit to allow the chorus to resound, especially when it splits into parts.

Despite some differences in performance practice, "Song No. 19" serves as an example of a successful effort by the Church to recontextualize, revitalize, and ultimately help sustain Kenyah song in a manner that has been readily acceptable to the congregation. Through the use of isiu belian-the special language of song-coupled with recognizable traditional melodies, parishioners were able not only to honor God without violating any other spirit but also to do so in a manner that was unmistakably Kenyah. Belian dadu' indeed have come full circle, arising as an indigenous adaptation of Protestant hymn singing for use in recreational circumstances, before being 
readapted by the Catholic church as sustainable and uniquely Kenyah songs of worship.

\section{Religion, Religiosity, and Sustainability Reconsidered}

What can be learned from the case of Kenyah tebada' and belian dadu' in terms of the link between religion, religiosity, and sustainability of traditional performing arts? Most important, these examples underscore the power of the community itself in determining the direction of its arts in a post-conversion environment. Among the Kenyah, decisions to abandon or adapt old artistic practices, or simply to adopt new ones were made according to the converts' overarching understanding, first, of the nature of the spirit world, and second, of the way their relationships with multiple entities within that world should be approached or reconciled.

Following Kenyah conversion to Christianity, the rhyming, formulaic language of tebada', formerly used to summon and speak with non-Christian spirits, was deliberately abandoned, despite a concerted effort by local Catholic leaders in Sarawak to incorporate it into the mass. Meanwhile, Protestant Kenyah in Kalimantan adapted the style of church hymns to develop long-dance songs, a new recreational genre cast in the unique, also spirit-rooted but non-invocatory formulaic language of song, isiu belian. The use of isiu belian allowed the new belian dadu' repertoire quickly to be absorbed into the broader Kenyah tradition and thus be perceived as both ancient and indigenous. Once these long-dance songs gained popularity in Sarawak, the Catholic church successfully readapted them for use in the service. The key to the songs' success in a Christian ritual context was the employment not only of tunes that had become indigenized within the Kenyah community, but also the isiu belian, which from a Kenyah perspective, was a powerful, respectable, distinctly Kenyah expression that posed no threat to the status of current or former relationships with the spirit realm.

However, as has been the case with many other sustainability interventions (Titon, $2009 \mathrm{~b}$ ), it should be noted that this development may simultaneously have tipped the musical eco-system in posing a threat to the original long-dance songs. During the last decade or so, there has been a growing tendency among younger Kenyah to know only the comparatively limited Christian texts of these melodies, due to insufficient (if any) exposure to the broader pool of song-language formulae employed in purely recreational long-dance performances. Returning to Grant's (2014) concept of the mutually sustaining connection between music and language, the shrinkage of the formulaic vocabulary of $i$ siu belian - the emblem of truly Kenyah song - may carry grave implications for the whole concept of Kenyah vocal performance. In contemporary society, the avenue toward ensuring the viability and integrity of Kenyah song tradition may indeed be through the church by increasing the variety of songlanguage formulae employed in the songs of the Kenyah Christian services.

Ultimately, the Kenyah of Kalimantan and Sarawak have shown that sustainability efforts in post-conversion settings must be guided by a solid grasp of the social and spiritual contexts and constructs in which music traditions are embedded. In other words, one must be cognizant not only of the ways in which the art forms operate within a particular religious environment but also the way in which religion fits into a community's broader religiosity. Without such knowledge, efforts toward sustainability 
may be made in vain. Indeed, sometimes it may be best to focus simply on preservation through documentation when traditions - such as tebada' - face abandonment. In other circumstances, by contrast, strategic adaptation of traditions - as exemplified by the history of belian dadu' long-dance songs - may inject vitality into both traditional arts and new spiritual practices.

\section{Endnotes}

1 This paper is an expanded version of a short presentation delivered at the symposium of the Performing Arts of Southeast Asia (PASEA) study group of the International Council for Traditional Music in Penang, Malaysia, July 31-August 6, 2016. I would like to thank Salomon Gau for his generous and enthusiastic help with translation of some of the Kenyah verses.

2 For a more detailed account of the history of gongs among the Kenyah Uma' Jalan, see Gorlinski (1994).

${ }^{3}$ For an extensive and extraordinarily researched account of these related Borneo peoples, see Jérôme Rousseau's Central Borneo: Ethnic Identity and Social Life in a Stratified Society (1990).

${ }^{4}$ This often repeated subgroup count stems from the work of Herbert Whittier in the 1970s (see Whittier, 1973; Whittier, 1978). Since that time, population and subgroup counts have become more challenging, with downriver migrations, ethnically mixed marriages, and population statistics that group most indigenous minorities into a few conglomerate categories.

${ }^{5}$ This movement has been propelled by many factors, including — but by no means limited to-government-sponsored, or sometimes government-imposed, resettlement programs. In Indonesia, these programs were implemented primarily to ease administration of remote peoples. In Malaysia, the planned flooding associated with the construction of hydroelectric dams has been the motivation behind the government's relocation of many upriver villages.

6 The longhouses at Sungai Asap, in Sarawak, serve as a case in point. These structures were built in the final years of the 20th century to house the residents of 15 villages that lay in the projected flood zone of the Bakun Dam. The dam itself was completed in 2011 (Eguavoen \& Laube, 2016).

${ }^{7}$ Originally, the religion now designated adet pu'un had no label other than adet. The $p u$ 'un (ancient, original) modifier was added in more recent times to distinguish the earlier religion from later ones-i.e., adet Bungan and adet Kristen (Christianity).

${ }^{8}$ For a summary of adet Bungan as "a religious movement" see Winzeler (2012). 
${ }^{9}$ Many of these conversions happened in the wake of the military coup of 1965 and subsequent systematic massacre of followers of the Indonesian Communist Party (PKI). Under the new national government, military officers who were placed in the Apau Kayan urged villagers to adopt one of the religions officially recognized by the state. At the time, those religions included Islam, Hinduism, Buddhism, Catholicism, Protestantism, or Confucianism. (Confucianism was removed from the list in 1979 [Suryadinata, 2003].) If the Kenyah did not adopt an official religion, they would be considered religionless, which was equated with being communist, which ultimately put their lives in danger. As recounted by one Kenyah Uma' Jalan father, "an officer held a bible in one hand and a gun in the other and asked, 'which do you choose?"' Regardless of whether the man's story is fact or folklore, the Kalimantan Kenyah experienced strong pressure to convert in the late 1960s and early 1970s. For a similar account, see Urano (2013).

10 Tan Chee-Beng (2016) has insightfully analyzed the importance of the convenience factor in the decision of the Kenyah Badeng of the upper Balui basin in Sarawak gradually to adopt Christianity in the second half of the 20th century.

${ }^{11}$ See, for example the Sarawak Annual Report (1962):

Borneo has its very own vital arts and crafts. Inevitably these are threatened by the greatly accelerated and sometimes uncontrollable impact of western civilization. In particular, the influence of Government education and mission activities has very generally been to create a new set of values the significance of which is often imperfectly understood by the Native peoples most affected. (p. 302)

12 For more on ritual languages of Southeast Asia, see James J. Fox (ed.), To Speak in Pairs: The Ritual Languages of Eastern Indonesia (1988).

${ }^{13}$ For a more detailed account of long-dance songs, supported by streaming audio and video examples of both village and city performances of belian dadu', see Gorlinski (2016). Note that in that article, the repertoire is labeled kendau kancet ("dance songs"), using Kenyah Uma' Jalan terminology. For transcriptions, translations, and short histories of many of these songs see Chong (1998).

14 See Gorlinski (1995) for an analysis of the nature and structure of the language of Kenyah song.

${ }^{15}$ Around the turn of the 21 st century, I was told that even if sung in Kenyah, church hymns are not Kenyah songs. At the time, the language of church singing continued to be ordinary Kenyah language, as opposed to isiu belian, the formulaic language of song. It will be interesting to observe whether this perception changes, as song language becomes more prominent in Christian services. 
16 This did not mean, however, that the spirits were not listening. The story spirits (bali tekena'), for example, certainly listened to the tales of their exploits as recounted through kerintuk epic-narrative singing. For many Kenyah of the upper Baram region, kerintuk and the language of the bali tekena' was considered the paragon, if not the ultimate source, of Kenyah song language.

\section{References}

Chong, P. L. (1998). Folk songs of Sarawak: songs from the Kenyah community. Kuching: Dayak Cultural Foundation.

Chua, L. (2012). The Christianity of culture: Conversion, ethnic citizenship, and the matter of religion in Malaysian Borneo. New York, NY: Palgrave.

Conley, W. W. (1976). The Kalimantan Kenyah: A study of tribal conversion in terms of dynamic cultural themes. Nutley, NJ: Christian Reformed Publishing Co.

Davidson, J. S., \& Henley, D. (2007). The revival of tradition in Indonesian politics: The deployment of adat from colonialism to indigenism. London: Routledge.

Eguavoen, I., \& Laube, W. (2016). Negotiating local governance: Natural resources management at the interface of communities and the state. Münster, Germany: LIT Verlag.

Fox, J. J. (Ed.). (1988). To speak in pairs: Essays on the ritual languages of eastern Indonesia. New York: Cambridge University Press.

Galvin, A. D. (1972). Sebayang singget tau (isiu Kenyah) (Prayers for every day [Kenyah language].). Miri, Sarawak. Malaysia.

Galvin, A. D. (1975). Sebayang singget tau (isiu Kenyah) (Prayers for every day [Kenyah language].). Miri, Sarawak. Malaysia.

Gorlinski, G. (2016). Kenyah kendau kancet choral singing of Indonesian and Malaysian Borneo: Reflections on a triptych. In Andrew McGraw and Sumarsam (Eds.), Performing Indonesia. Washington, D.C.: Freer and Sackler Galleries, Smithsonian Institution. Retrieved from http://www.asia.si.edu/ research/performing-indonesia/article-gorlinski.php

Gorlinski, V. K. (1995). Songs of honor, words of respect: Social contours of Kenyah Lepo' Tau versification, Sarawak, Malaysia. (Unpublished doctoral dissertation). University of Wisconsin-Madison, Wisconsin.

Gorlinski, V. K. (1994). Gongs among the Kenyah Uma' Jalan: Past and present position of an instrumental tradition. Yearbook for Traditional Music, 26, 8199.

Grant, C. (2014). Music endangerment: How language maintenance can help. Oxford: Oxford University Press. 
Her Majesty's Stationery Office. (1962). Sarawak annual report 1961. London: Her Majesty's Stationery Office.

Matusky, P., \& Tan, S. B. (2004). The music of Malaysia: The classical, folk and syncretic traditions. London: Ashgate.

Mlenga, J. (2016). Dual religiosity in northern Malawi: Ngonde Christians and African traditional religion. Mzuzu, Malawi: Mzuni Press.

Rousseau, J. (1990). Central Borneo: Ethnic identity and social life in a stratified society. Oxford: Clarendon Press.

Schippers, H., \& Grant, C. (Eds.). (2016). Sustainable futures for music cultures: An ecological perspective. Oxford: Oxford University Press.

Suryadinata, L., Arifin, E. N., \& Ananta, A. (2003). Indonesia's population: Ethnicity and religion in a changing political landscape. Singapore: Institute of Southeast Asian Studies.

Tan, C-B. (2016). It is easy when you are a Christian: Badeng Kenyah conversion to Christianity. Cultural and Religious Studies, 4(4), 254-272.

Titon, J. T. (2009a). Economy, ecology, and music: An introduction. The World of Music, 51(1), 5-15.

Titon, J. T. (2009b). Music and sustainability: An ecological viewpoint. The World of Music, 51(1), 119-137.

Tyson, A. D. (2010). Decentralization and adat revivalism in Indonesia: The politics of becoming indigenous. London: Routledge.

Urano, M. (2013). The limits of tradition: Peasants and land conflicts in Indonesia. Melbourne, Australia: TransPacific Press.

Whittier, H. (1978). The Kenyah. In V.T. King (Ed.), Essays on Borneo societies (pp. 92-123). Oxford: Oxford University Press.

Whittier, H. (1973). Social organization and symbols of social differentiation: An ethnographic Study of the Kenyah Dayak of East Kalimantan (Borneo). (Unpublished doctoral dissertation). Michigan State University, East Lansing, Michigan.

Winzeler, R. (2012). Anthropology and religion: What we know, think, and question. Lanham, MD: Rowman \& Littlefield. 